\title{
FAKTOR PENYEBAB PENUNDAAN OPERASI ELEKTIF DI RUMAH SAKIT PEMERINTAH DI SEMARANG
}

\author{
Fitria Siswi Amurwani*, Muhamad Rofi' $i^{* *}$ \\ *)Rumah Sakit Umum Pusat Dr. Kariadi Semarang (email: siswi.fitria@yahoo.com) \\ **)Staf Pengajar Program Studi Ilmu Keperawatan, Fakultas Kedokteran, Universitas Diponegoro \\ (email: rofiimuhamad@yahoo.com)
}

Corresponding Author : rofiimuhamad@yahoo.com

\begin{abstract}
ABSTRAK
Angka penundaan operasi elektif di Rumah Sakit Pemerintah Di Semarang masih tinggi dan kurang sesuai dengan indikator mutu klinis rumah sakit. Penundaan operasi elektif disebabkan karena faktor medis, faktor pasien, faktor logistik dan administrasi dan faktor lain-lain. Tujuan penelitian ini untuk mengetahui gambaran penyebab penundaan operasi elektif di Rumah Sakit Pemerintah di Semarang. Penelitian ini merupakan jenis penelitian deskripsi kuantitatif dengan metode survei. Pengumpulan data dilakukan dengan lembar observasi dan check list. Jumlah responden sebanyak 54 orang dengan teknik sampling jenuh. Data yang diperoleh diolah dengan menggunakan analisa univariat untuk mengetahui distribusi dan persentase masing-masing variabel. Karakteristik responden sebagian besar adalah laki-laki (53,7\%), usia paling banyak 41-60 tahun (40,7\%), tingkat pendidikan paling banyak SMA $(25,9 \%)$, pekerjaan lain-lain berjumlah $(53,7 \%)$, paling banyak dirawat di kelas III $(66,7 \%)$ dengan fasilitas Jamkesmas $(42,6 \%)$. Lama penundaan operasi elektif paling banyak $>5$ hari $(38,9 \%)$. Penundaan operasi elektif di Rumah Sakit Pemerintah di Semarang disebabkan karena faktor medis $(48,1 \%)$, faktor pasien $(14,8 \%)$, faktor logistik dan administrasi $(27,8 \%)$ dan faktor lain-lain (9,3\%). Penundaan operasi elektif paling banyak disebabkan karena faktor medis dan sebagian besar disebabkan karena perubahan akut fungsi kardiovaskuler dan pernapasan, nilai laboratorium tidak normal dan pasien menolak operasi. Perawat diharapkan melakukan monitoring lebih intensive terhadap fungsi kardiovaskuler dan pernapasan, nilai laboratorium dan memberikan edukasi serta motivasi pasien pre-operasi.
\end{abstract}

Kata kunci: Penundaan, Operasi Elektif 


\section{PENDAHULUAN}

Perkembangan ilmu pengetahuan dan teknologi serta peningkatan tingkat pendidikan dan pengetahuan masyarakat menuntut pihak manajemen rumah sakit memberikan pelayanan yang berkualitas untuk memenuhi kepuasan pelanggan total (Sabarguna, 2008). Kepuasan pasien berhubungan dengan mutu pelayanan rumah sakit. Salah satu indikator mutu pelayanan rumah sakit yaitu angka penundaan operasi. Penundaan operasi elektif merupakan masalah di banyak rumah sakit yang dapat menyebabkan ketidakpuasan pasien, meningkatkan biaya dan memperpanjang masa rawat pasien di rumah sakit. Penundaan operasi elektif juga menggambarkan kurang efisiennya manajemen ruang operasi suatu rumah sakit (Ebirim, 2012).

Penelitian yang dilakukan di AyubTeaching Hospital, Frontier Medical College, Abbottabad tentang pembatalan operasi elektif pada Juli 2006 sampai Juni 2007 didapatkan data dari 3756 pasien yang dijadwalkan operasi, 935 (25\%) operasi mengalami penundaan. Penyebab penundaan operasi ada beberapa macam, yaitu $338(36 \%)$ penundaan operasi disebabkan ketidakcukupan waktu operasi, $296(31,6 \%)$ karena alasan medis dan 152 (16,2\%) karena kekurangan tempat tidur. Selanjutnya pembatalan yang dilakukan oleh ahli anestesi sebanyak 399 (43\%), oleh dokter bedah 367 (39\%) dan 170 (18\%) karena alasan organisasi (Zafar, 2007).

Penelitian yang dilakukan di rumah sakit pendidikan di Enugu Nigeria tentang penyebab penundaan operasi elektif didapatkan hasil $28 \%$ dari 1015 operasi elektif tertunda karena beberapa penyebab, dua penyebab utama karena waktu ruang operasi yang tidak cukup, yaitu sebanyak 24,3 $\%$ dan pasien yang tidak siap pada hari operasi sebanyak 21,13\%. Penyebab lainnya yaitu penyakit medis yang tidak terkontrol, hasil laboratorium yang tidak normal dan pasien tidak mampu membayar biaya operasi (Ebirim, 2012). Sedangkan penelitian yang dilakukan oleh Gonzales Arevalo, dkk pada sebuah rumah sakit umum di Madrid, Spanyol pada tahun 2009 tentang penyebab penundaan operasi elektif, didapatkan hasil 6,5\% (2559 dari 39115 operasi elektif) mengalami penundaan operasi. Penyebabnya antara lain karena alasan medis $50 \%$, berhubungan dengan faktor pasien $23 \%$ dan faktor administratif dan logistik $25 \%$. Lebih spesifik lagi penyebab yang paling umum diantaranya karena infeksi atau demam $18 \%$, pasien tidak siap operasi $20 \%$ dan $23 \%$ disebabkan karena kekurangan waktu ruang operasi (Arevalo, 2009).

Angka penundaan operasi elektif pasien di Rumah Sakit Pemerintah di Semarang masih tinggi. Pedoman indikator mutu klinis Rumah Sakit Pemerintah di Semarang menyebutkan bahwa angka tunda operasi kurang dari 5\%. Berdasarkan laporan bulanan ruang bedah wanita dan anak mengenai penundaan tindakan operasi didapatkan data bahwa penundaan tindakan operasi pada tahun 2013 yaitu bulan Januari sebesar 6,3\%, Februari 4,9\%, Maret 5,4\%, April 6,7\%, Mei 5,3\% dan Juni $6,4 \%$.

Studi pendahuluan yang dilakukan peneliti di ruang bedah wanita dan anak mengenai penundaan tindakan operasi dari tanggal 26 Juni sampai dengan tanggal 2 Juli 2013 didapatkan hasil dari 25 pasien yang dijadwalkan tindakan operasi 6 diantaranya mengalami penundaan operasi. Faktor yang menyebabkan tertundanya tindakan operasi yaitu 1 pasien karena keadaan umum yang tidak memungkinkan, 1 pasien karena peralatan operasi yang rusak dan sisanya karena faktor tidak adanya PICU ataupun ICU untuk perawatan post operasi.

\section{METODE PENELITIAN}


Jenis penelitian ini adalah penelitian deskripsi kuantitatif. Metode penelitian yang digunakan adalah survei. Populasi pada penelitian ini adalah seluruh pasien preoperasi elektif yang mengalami penundaan operasi di Rumah Sakit Pemerintah di Semarang.

Pengambilan sampel pada penelitian ini menggunakan teknik sampling jenuh. Cara pengambilan sampel adalah dengan mengambil data seluruh pasien yang mengalami penundaan operasi elektif di ruang operasi Rumah Sakit Pemerintah di bulan Desember 2013 sejumlah 54 pasien, kemudian mendatangi ruang tempat pasien dirawat untuk mendapatkan data tentang penyebab penundaan operasi elektif melalui Perawat Penanggung Jawab Pasien (PPJP).

Alat yang digunakan dalam pengumpulan data adalah lembar observasi yang berisi data demografi pasien dan check list penyebab penundaan operasi. Check list berisi data karakteristik pasien yang meliputi : Inisial pasien, umur, jenis kelamin, pendidikan, pekerjaan dan status pembiayaan serta penyebab penundaan operasi : faktor medis, faktor pasien, faktor logistik dan administrasi, dan faktor lain-lain.

\section{HASIL PENELITIAN}

\section{A. Karakteristik Responden}

Hasil distribusi frekuensi pasien yang menjadi responden di Rumah Sakit Pemerintah di Semarang Semarang pada tabel 1 menunjukkan bahwa frekuensi jenis kelamin terbanyak pada kategori laki-laki dengan jumlah 29 responden (53.7\%), frekuensi terbanyak pada kategori usia 4160 tahun sejumlah 22 responden (40,7\%). pendidikan SMA dengan jumlah 14 responden $(25,9 \%)$, pada kelas perawatan frekuensi terbanyak pada kategori kelas III dengan jumlah 36 responden $(66,7 \%)$ dan paling sedikit dirawat di VIP berjumlah 3 responden $(5,6 \%)$. Pekerjaan lain-lain dengan jumlah 29 responden $(53,7 \%)$. Terbanyak mengalami penundaan $>5$ hari yaitu sejumlah 21 responden $(16,7 \%)$. Berdasarkan status pembiayaan, frekuensi terbanyak adalah Jamkesmas yaitu sejumlah 23 responden $(42,6 \%)$.

Tabel 1. Distribusi Frekuensi Berdasarkan Karakteristik Responden Yang Mengalami Penundaan

\begin{tabular}{|c|c|c|}
\hline Karakteristik & Jumlah & Persentase (\%) \\
\hline \multicolumn{3}{|l|}{ Jenis Kelamin } \\
\hline Perempuan & 25 & 46.3 \\
\hline Laki-laki & 29 & 53.7 \\
\hline \multicolumn{3}{|l|}{ Usia } \\
\hline 1-20tahun & 9 & 16,7 \\
\hline 21-40tahun & 14 & 25,9 \\
\hline 41-60tahun & 22 & 40,7 \\
\hline 60-80tahun & 9 & 16,7 \\
\hline \multicolumn{3}{|l|}{ Pendidikan: } \\
\hline Tidak tamat SD & 11 & 20,4 \\
\hline SD & 6 & 11,1 \\
\hline SMP & 10 & 18,5 \\
\hline SMA & 14 & 25,9 \\
\hline DIII & 8 & 14,8 \\
\hline Sarjana & 5 & 9,3 \\
\hline \multicolumn{3}{|l|}{ Kelas } \\
\hline III & 36 & 66,7 \\
\hline II & 11 & 20,4 \\
\hline
\end{tabular}




\begin{tabular}{lcc} 
I & 4 & 7,4 \\
VIP & 3 & 5,6 \\
\hline Pekerjaan & & \\
PNS/TNI/POLRI & 10 & 18,5 \\
Swasta & 15 & 27,8 \\
Lain-lain & 29 & 53,7 \\
Lama penundaan & & \\
1 hari & & \\
2 hari & 9 & 16,7 \\
3 hari & 8 & 14,8 \\
4 hari & 11 & 20,4 \\
5 hari & 4 & 7,4 \\
5 hari & 1 & 1,9 \\
& 21 & 38,9 \\
Status & & \\
pembiayaan & & \\
Jamkesmas & 29 & 42,6 \\
Jamkesda & 11 & 20,4 \\
Jamsostek & 2 & 3,7 \\
Askes PNS & 12 & 22,2 \\
Umum & 6 & 11,1 \\
\hline
\end{tabular}

\section{B. Penyebab Penundaan Operasi Elektif}

Tabel 2. Distribusi Frekuensi Faktor Penyebab Penundaan Operasi Elektif Di RS Pemerintah Area Semarang

\begin{tabular}{lcc}
\hline Faktor Penyebab & Jumlah & $\begin{array}{c}\text { Persentase } \\
(\%)\end{array}$ \\
\hline Faktor medis & 26 & 48,1 \\
Faktor pasien & 8 & 14,8 \\
Faktor logistik dan & 15 & 27,8 \\
administrasi & & \\
Faktor lain-lain & 5 & 9,3 \\
\hline \multicolumn{1}{c}{ Total } & 54 & $100 \%$ \\
\hline
\end{tabular}

Berdasarkan tabel 2 diketahui bahwa dari 54 penundaan operasi elektif di Rumah Sakit Pemerintah di Semarang Semarang yang terjadi pada bulan Desember 2013, 26 penundaan operasi $(48,1 \%)$ disebabkan oleh faktor medis, 15 penundaan operasi $(27,8 \%)$ disebabkan oleh faktor logistik dan administrasi, 8 penundaan operasi disebabkan oleh faktor pasien dan 5 penundaan operasi disebabkan oleh faktor lain-lain. 
Tabel 3. Distribusi Frekuensi Penyebab Penundaan Operasi Elektif Di Rumah Sakit Pemerintah Area Semarang

\begin{tabular}{|c|c|c|c|}
\hline No & Faktor Penyebab & Jumlah & Persentase $(\%)$ \\
\hline \multicolumn{4}{|c|}{ Faktor Medis } \\
\hline 1 & Perubahan diagnosa & 0 & 0,0 \\
\hline 2 & Non Indikasi bedah & 0 & 0,0 \\
\hline 3 & $\begin{array}{l}\text { Perubahan akut fungsi kardiovaskuler dan } \\
\text { pernapasan }\end{array}$ & 11 & 20,4 \\
\hline \multicolumn{4}{|c|}{ Faktor medis } \\
\hline 4 & Gangguan pembekuan & 0 & 0,0 \\
\hline 5 & Tidak memenuhi prosedur puasa & 0 & 0,0 \\
\hline 6 & Pengosongan usus yang kurang & 0 & 0,0 \\
\hline 7 & Hasil laboratorium tidak normal & 8 & 14,8 \\
\hline 8 & Infeksi & 1 & 1,9 \\
\hline 9 & Demam & 2 & 3,7 \\
\hline 10 & Gangguan fungsi hepar dan ginjal & 2 & 3,7 \\
\hline 11 & Team bedah tidak lengkap & 2 & 3,7 \\
\hline \multicolumn{4}{|c|}{ Faktor pasien } \\
\hline 12 & Pasien menolak operasi setelah persetujuan & 8 & 14,8 \\
\hline 13 & Jaminan pembayaran belum lengkap & 3 & 5,6 \\
\hline \multicolumn{4}{|c|}{ Faktor Logistik dan administrasi } \\
\hline 14 & Kekurangan waktu operasi & 5 & 9,3 \\
\hline 15 & Terdapat kasus emergensi & 0 & 0,0 \\
\hline 16 & Kekurangan ruang pemulihan & 0 & 0,0 \\
\hline 17 & Tidak tersedia ICU/PICU & 5 & 9,3 \\
\hline 18 & Kekurangan/belum informed concent & 1 & 1,9 \\
\hline 19 & Kekurangan perlengkapan & 1 & 1,9 \\
\hline 20 & Darah tidak tersedia & 0 & 0,0 \\
\hline 21 & Kesalahan penjadwalan & 0 & 0,0 \\
\hline 22 & Gaktor lain-lain & 5 & 9,3 \\
\hline & Total & 54 & $100 \%$ \\
\hline
\end{tabular}

Berdasarkan tabel 3 diketahui bahwa penyebab penundaan operasi di Rumah Sakit Pemerintah di Semarang Semarang bulan Desember 2013 adalah perubahan akut fungsi kardiovaskuler dan pernapasan 11 responden $(20,4 \%)$, hasil laboratorium tidak normal 8 responden $(14,8 \%)$, pasien menolak operasi setelah persetujuan 8 responden $(14,8 \%)$, kekurangan waktu operasi 5 responden $(9,3 \%)$, tidak tersedia ICU/PICU 5 responden $(9,3 \%)$, administrasi belum lengkap 3 responden $(5,6 \%)$. Penyebab yang lain yaitu demam, tim bedah belum lengkap, gangguan fungsi hepar dan ginjal masing-masing 2 responden $(3,7 \%)$ dan infeksi, belum inform concent, kekurangan perlengkapan masing-masing 1 responden $(1,9 \%)$ serta penyebab lain-lain sebanyak 5 responden $(9,3 \%)$.

\section{PEMBAHASAN}


Distribusi frekuensi jenis kelamin yang menjadi responden penundaan operasi elektif di Rumah Sakit Pemerintah di Semarang Semarang, pada kategori laki-laki dengan jumlah 29 responden $(53,7 \%)$ lebih banyak dibandingkan perempuan. Hasil ini kurang sesuaidengan hasil penelitian yang dilakukan di sebuah rumah sakit umum di Madrid Spanyol, dimana penundaan operasi pada pasien perempuan sebesar $51 \%$ dan pasien laki-laki $49 \%$. Jumlah pasien laki-laki yang mengalami penundaan operasi elektif lebih banyak dibandingkan perempuan disebabkan karena jumlah pasien laki-laki yang menjalani operasi elektif pada bulan Desember 2013 di Rumah Sakit Pemerintah di Semarang lebih banyak dibandingkan dengan pasien perempuan (59\% laki-laki dan $41 \%$ pasien perempuan). Penelitian yang dilakukan di pelayanan kesehatan nasional di Inggris menunjukkan bahwa laki-laki lebih banyak mengalami penundaan operasi elektif (Jones, 2012). Sedangkan penelitian yang dilakukan di Ayub Teaching Hospital menunjukkan bahwa penundaan operasi elektif yang dipengaruhi oleh gender antara laki-laki dan perempuan $6 \%$ berbanding $7 \%$. Jenis kelamin tidak berpengaruh pada penundaan operasi elektif(Zafar, 2007).

Tingkat usia responden yang mengalami penundaan operasi paling banyak berusia 41-60 tahun $(40,7 \%)$. Hasil ini kurang sesuaidengan hasil penelitian yang dilakukan di sebuah rumah sakit umum di Madrid Spanyol dimana penundaan operasi paling banyak terjadi pada usia 0-10 tahun (13\%) dan 21-30 tahun (9\%) (Zafar, 2007).

Kelas perawatan dan status pembiayaan dan pekerjaan responden, paling banyak adalah kelas perawatan kelas III $(66,7 \%)$ dengan status pembiayaan Jamkesmas $(42,6 \%)$ dan pekerjaan responden lain-lain $(53,7 \%)$. Hal ini dikarenakan pasien yang menjalani operasi elektif di Rumah Sakit Pemerintah di Semarang Semarang paling banyak dirawat di kelas III dengan fasilitas Jamkesmas. Penelitian yang dilakukan di pusat pelayanan kesehatan di Inggris menyebutkan bahwa penundaan operasi banyak terjadi pada kelompok pasien dengan sosial ekonomi rendah (Jones, 2012). Penelitian yang dilakukan di Major Teaching Referral Hospital di Jordan menunjukkan bahwa 23,0\% penundaan operasi elektif disebabkan karena pasien tidak datang saat operasi dan $5,8 \%$ diantaranya disebabkan karena alasan biaya (Mesmar, 2009).

Lama penundaan operasi elektif terbanyak yaitu lebih dari 5 hari sejumlah 21 responden $(38,9 \%)$, hal ini berkaitan dengan hasil penelitian dimana penyebab penundaan operasi terbanyak pada gangguan fungsi kardiovaskuler dan pernafasan. Pada pasien dengan gangguan fungsi kardiovaskuler dan pernafasan biasanya pasien dikirim lagi ke dokter pengirim untuk mendapatkan pengobatan dan baru dirawat lagi setelah kondisi baik (Hamli, 2007). Hasil penelitian yang dilakukan di English National Health Service menunjukkan bahwa lama penundaan operasi berkisar antara 1 jam dan hampir 9 jam (Jones, 2007).

Penyebab penundaan operasi elektif pada bulan Desember 2014 terbanyak disebabkan karena faktor medis yaitu sejumlah 26 responden $(48,1 \%)$, dan dari faktor medis tersebut 11 responden $(20,4 \%)$ karena perubahan akut fungsi kardiovaskuler dan pernafasan, 8 responden $(14,8 \%)$ karena hasil laboratorium tidak normal. Hasil ini lebih rendah jika dibandingkan dengan penelitian di Ayub Teaching Hospital dimana penundaan operasi elektif karena faktor medis yaitu sebesar 36\% (Perry \& Potter, 2005). Hasil penelitian yang dilakukan di Spanish General Hospital didapatkan hasil bahwa penundaan operasi yang disebabkan karena faktor gangguan akut fungsi pernapasan dan kardiovaskuler adalah $2 \%$, faktor demam $18 \%$, hasil laboratorium yang tidak normal 6,7\% (Zafar, 2007).

Data yang diperoleh peneliti dari ruang operasi Rumah Sakit Pemerintah di Semarang menyebutkan bahwa responden yang mengalami penundaan operasi elektif yang disebabkan karena faktor perubahan akut fungsi kardiovaskuler dan pernafasan, terbanyak disebabkan karena hipertensi yang tidak terkontrol dan selebihnya karena ditemukannya kelainan pada pemeriksaan EKG (adanya iskemik), sesak nafas dan pada anak-anak karena batuk dan pilek.

Penyakit kardiovaskuler meningkatkan resiko operasi dan bergantung pada keparahan gejala, tindakan operasi dapat ditunda sampai pengobatan medis dapat dilakukan untuk Angkasa / Efektivitas pemberian konseling keperawatan terhadap...Page $\mathbf{2 2}$ of $\mathbf{2 5}$ 
memperbaiki kondisi pasien (Smeltzer, 2002). Kesulitan pernafasan meningkatkan kemungkinan ateletaksis, bronkhopneumonia, dan gagal nafas ketika anestesi diberikan pada keadaan ventilasi yang tidak adekuat. Penting sekali mempertahankan ventilasi yang adekuat selama semua fase operasi, operasi biasanya dikontraindikasikan ketika pasien mengalami infeksi pernafasan (Sugiono, 2006).

Penyebab penundaan operasi terbanyak kedua dari faktor medis yaitu hasil laboratorium tidak normal $(14,8 \%)$ yang terdiri dari hiperglikemia dan anemia. Hasil ini lebih tinggi jika dibandingkan dengan penelitian yang dilakukan di Spanish General Hospital yaitu 6,7\% (Zafar, 2007). Pada pasien yang akan menjalani operasi elektif, apabila hasil urinalisis glukosanya positif, harus menjalani pemeriksaan analisis glukosa darah. Angka $>10 \mathrm{mmol} / \mathrm{l}$ pada pemeriksaan glukosa darah sewaktu atau $>7 \mathrm{mmol} / \mathrm{l}$ saat puasa mungkin mengisyaratkan diabetes. Kasus elektif harus ditunda untuk menegakkan diagnosis (Hamly, 2007). Anemia menyebabkan penurunan kemampuan darah mengangkut oksigen. Penurunan ini dikompensasi dengan meningkatkan curah jantung yang memerlukan peningkatan kerja jantung dan keadaan ini dapat meningkatkan resiko iskemik perioperasi (Hamly, 2007).

Perawat sebagai care giver memiliki peran strategis dalam persiapan operasi pasien. Dalam perawatan pre-operasi, perawat mengumpulkan riwayat kesehatan dan melakukan pemeriksaan fisik. Perawat juga membantu pasien untuk memahami perlunya pemeriksaan diagnostik (Hamly, 2007).

Penyebab penundaan operasi elektif karena faktor pasien yaitu pasien menolak operasi setelah persetujuan sejumlah 8 responden $(14,8 \%)$. Angka ini sangat tinggi jika dibandingkan dengan hasil penelitian di Ayub Teaching Hospital yaitu 0,4\% yang disebabkan karena pasien menolak tindakan operasi setelah persetujuandan 3\% di Spanish General Hospital (Perry \& Potter, 2005). Ketakutan yang dialami pasien seringkali membuat pasien dan keluarga mengambil keputusan untuk menolak tindakan operasi, dan kecemasan yang dialami pasien dapat berdampak terhadap berlangsungnya pelaksanaan operasi (Kuraesin, 2009). Perawat harus memberikan dorongan agar pasien dapat mengungkapkan ketakutan yang dialami. Perawat harus mendengarkan, memahami dan memberikan informasi yang membantu menyingkirkan ketakutan tersebut (Brunner \& Suddarth, 2002). Peran perawat dalam pemberian informed consent preoperasi adalah sebagai advocate dimana perawat membantu pasien memahami berbagai informasi yang diterima khususnya dalam pengambilan keputusan dan persetujuan atas tindakan yang akan diterimanya dan juga melindungi hak-hak pasien. Peran yang lain yaitu sebagai konselor dimana perawat membantu pasien mengatasi tekanan psikologisnya atau masalah sosial (Mahmud, 2010).

Penyebab penundaan operasi elektif karena faktor logistik dan administrasi terbanyak karena faktor kekurangan waktu operasi dan tidak tersedia ICU/PICU dimana masing masing sejumlah 5 responden $(9,3 \%)$. Karena faktor administrasi belum lengkap sebanyak 3 responden $(5,6 \%)$ dan selebihnya karena kekurangan perlengkapan dan pasien belum informed concent masing-masing 1 responden $(1,9 \%)$.

Hasil penelitian di Ayub Teaching Hospital menunjukkan bahwa angka penundaan operasi karena faktor kekurangan waktu operasi adalah $36 \%$. Ahli bedah yang tidak berpengalaman dengan prosedur yang ada menambah panjangnya waktu operasi(Perry \& Potter, 2005). Penelitian yang dilakukan di rumah sakit pendidikan di Lake Zone Tanzania menyebutkan bahwa penundaan operasi akibat keterlambatan waktu mulai operasi menyebabkan lama penundaan 1-9 jam dan paling banyak mengalami penundaan 1 jam dari penjadwalan (Chalya, 2011). Sedangkan penelitian di Spanish General Hospital penundaan karena kekurangan waktu operasi adalah 22,5\%. Kekurangan waktu dalam operasi adalah faktor penting dalam penundaan operasi elektif, dan kebanyakan waktu dalam ruang operasi dihabiskan karena keterlambatan dimulainya operasi, waktu diantara prosedur, persiapan dan pembersihan ruang operasi dan keterlambatan pengiriman pasien keruang operasi, semua ini bisa dikurangi dengan kedisiplinan (Zaffar, 2007). 
Penundaan operasi karena kekurangan ruang dan fasilitas ruang operasi dapat dicegah dengan cara perencanaan yang hati-hati dan efisiensi dari sumber daya rumah sakit yang terbatas, termasuk didalamnya ruang operasi dan fasilitasnya. Penertiban penjadwalan dan prosedur penerimaan lebih penting dibandingkan penambahan sumber daya rumah sakit (Mesmar, 2009).

Frekuensi penyebab penundaan operasi elektif karena faktor lain-lain yaitu 5 responden $(9,3 \%)$. Dari 5 responden tersebut, 2 responden terjadi pada anak-anak karena harus dilakukan vena sectie dulu. Vena sectie diperlukan untuk mendapatkan akses intravena dalam pemberian obat dan cairan pre dan post operasi. Jika faktor kecepatan sangat penting dan pemasangan jarum/ kateter di vena perifer sulit, pada anak balita lebih baik dilakukan kanulasi intraoseus yang kemudian dilanjutkan dengan kanulasi vena besar atau seksi vena untuk pemberian obat dan cairan lanjutan (Atjeh, 2012). Kasus harus ditangguhkan bila operasi dianggap membahayakan jika diteruskan karena alasan-alasan logistik atau alasan yang terkait penderita (Hamly, 2007).

\section{KESIMPULAN DAN SARAN}

Penundaan operasi yang disebabkan oleh faktor medis sebanyak 26 pasien $(48,1 \%)$, terbanyak karena faktor perubahan akut fungsi kardiovaskuler dan pernafasan $(20,4 \%)$. Penundaan operasi yang disebabkan oleh faktor pasien sebanyak 8 pasien $(14,8 \%)$,yaitu pasien menolak operasi setelah persetujuan. Penundaan operasi yang disebabkan oleh faktor logistik dan administrasi sebanyak 15 pasien $(27,8 \%)$, terbanyak karena kekurangan waktu operasi dan tidak tersedia ICU/PICU (masing-masing 9,3\%). Penundaan operasi yang disebabkan oleh faktor lain-lain sebanyak 5 pasien (9,3\%), 2 diantaranya karena akses intravena yang sulit.Perawat perlu melakukan monitoring lebih ketat terhadap fungsi kardivaskuler dan pernafasan, nilai laboratorium dan memberikan edukasi serta motivasi pada pasien pre operasi.

\section{DAFTAR PUSTAKA}

Arevalo, G, et al. (2009). Causes for Cancellation of Elective Surgical Proceduresin a Spanish General Hospital. Anaesthesia 64, pages 487-493.

Atjeh, I. (2012). Akses Vaskuler pada Pediatrik.

Brunner \& Suddarth. (2002). Buku Ajar Keperawatan Medikal Bedah. Alih Bahasa Monika Ester. Jakarta : EGC.

Chalya, P. L. (2011). Causes and Pattern of Cancellation of Elective Surgical Operation in University Teaching Hospital.

Ebirim L.N., et al. (2012). Causes of Cancellation of Elective Surgical Operations at a Teaching Hospital University. Journal of Medicine and Medical Sciences. Vol. 3(5) pp. 297-301.

Jones, S. (2012). Cancelled Surgeries and Payment by Result in the English National Health Service.

Kuraesin. (2009). Faktor-Faktor yang Berhubungan Dengan Tingkat Kecemasan Pasien Yang Akan Menjalani Operasi Di RSUP Fatmawati.

Mahmud. (2010). Peran Perawat dalam Informed Consent Preoperasi di Ruang Bedah RS Pemangkat Kalimantan Barat.

Mesmar,et all. (2009). ReasonFor Cancellation of Elective operation of a Major Teaching Referal Hospital in Jordan.

Perry, P. (2005). Fundamental of Nursing. Jakarta : EGC.

Hamly, P.R. \& Sainsbury, M.C. (2007). Manajemen Perioperatif : Penatalaksanaan Pasien Bedah di Bangsal. Jakarta : EGC.

Sabarguna, B.S. (2008). Pemasaran Pelayanan Rumah Sakit. Jakarta : Sagung Seto. Angkasa / Efektivitas pemberian konseling keperawatan terhadap...Page $\mathbf{2 4}$ of $\mathbf{2 5}$ 
Smeltzer, S. (2002). Buku Ajar Kepererawatan Medikal Bedah. Jakarta: EGC.

Sugiyono. (2006). Statistik untuk Penelitian. Bandung: Alfabeta.

Zafar, A, et al. (2007). Cancelled Elective General Surgical Operations in Ayub Teaching Hospital. Journal of Ayub Med Coll Abbottabad. 